\title{
THE STUDY OF NUTRITIONAL VALUE FROM GRESIK TRADITIONAL FOOD PRODUCTS
}

\author{
Yunita Siti Mardhiyyah \\ Departemen Teknologi Industri Pertanian, Universitas Internasional Semen Indonesia \\ Email : yunita.mardhiyyah@uisi.ac.id
}

\begin{abstract}
Gresik is well known as one of the Islamic based tourism towns in East Java. This Islamic tourism encourages the development of typical souvenirs business in Gresik especially in food sector. Some Gresik traditional food are often used as souvenirs, such as pudak, jubung, and ayas. High sale promotes product innovation, especially in terms of taste creations, preservation / shelf life, as well as packaging. Unfortunately, these product innovation have not been supported with information related to product nutritional value. The nutritional value is important, considering the usage of information in food labelling as well as for the materials, process and packaging basic innovation. The study of Gresik traditional food nutritional value products consists of two stages, they were field-related observation and laboratory testing. Field observations were done to obtain information on raw materials and production processes from pudak, jubung and ayas. As for the test of nutritional value was done by proximate test. The results showed that pudak has moisture content (55.6\%) twice higher than jubung and ayas $(25.0 \%$ and $22.7 \%$, respectively). All three products have a low fat content, which was below $1.0 \mathrm{~g}$ per serving. The protein content is also relatively low, i.e. only 2.1-2.8\%. All three of these products are carbohydrate sources with the amount of 40.8-73.4\% which gives a caloric amount of 120-185 kcal per serving. Implementation of nutritional information in food label could also give added value to the product.
\end{abstract}

Keyword: Traditional food, nutrition, Gresik, pudak, jubung, ayas

\section{INTRODUCTION}

Indonesia is well known as tourism country, not only for the nature but also for Indonesian heritage culture. Ancient Islamic heritage culture of Gresik, East Java is one of favorite tourism destination in Indonesia. There were two main Java Islamic spreaders (commonly called as wali songo) that being burned in Gresik, namely Sunan Giri and Sunan Gresik or Maulana Malik Ibrahim. In addition to these two wali songo tombs, Gresik also has several Islamic cultural development sites, and also Islamic boarding schools (commonly called as pesantren) which are quite well known on Java island. The tourism sector and also the pesantren education then attract the attention of the community outside Gresik and at the same time encourage the development of souvenir industry, including souvenir of Gresik traditional food.

Traditional food is specifically food that produced by people in certain areas with typical raw materials or local regions (Suter, 2014). Every region in Indonesia has their own traditional food because of the diversity of geographical and cultural conditions. Gresik regency as one of the agricultural regions is well known for having agricultural based traditional foods such as like pudak, ayas and jubung.

Those three types of food products are widely sold in tourist destinations in Gresik city and used as souvenirs. Thus the products became one of Gresik city brand. Even CV Pitutur Luhur in Gresik, made a 
batik motif in the effort to create branding of Gresik city (Agustina \& P, 2017). The high demand for traditional food products has driven various product innovations, such as variant creations or flavors, packaging and also efforts to increase shelf life. Like pudak that not only have an original taste, but also a taste of pandanus, chocolate and even strawberries. However, until now there has been no research discussing the characteristics and quality of products, especially from nutritional value aspect. Information on nutritional value is important to provide health information to consumers, to dedicate the product development, shelf life improvement and to provide special information or claims. The product could be developed as highfiber food (functional food), emergency food (high calories), and so on. Specific information that also could be informed are allergens, serving sizes, or specific records for people with diseases such as diabetes.

Analysis of the nutritional content of traditional foods is important to consider the emergence of inappropriate stereotypes of traditional food. Usually, traditional food is considered to contain lots of cholesterol (or other bad components), high calories or less nutritious and promotes many diseases such as toothache, diabetes, obesity and so on. Nutritional value analysis of food products consists of several components, for example the content of macro nutrients, sugar, saturated fats and unsaturated fats, salt and others.

From nutritional value analysis thus the studies can be carried out regarding further product development. Some traditional food products have good nutritional value and are even suitable to be developed for other types of food. It has stated that at present, traditional foods are not only highlighted by their functions as typical souvenirs of the region, but begin to be developed towards functional food or food with tertiary (healthy) functions
(Suter, 2014). Meanwhile, this tertiary function can of course be known and claimed, if the primary (nutrition) and secondary (sensory) functions have been fulfilled. Thus, the study of nutritional values from Pudak, Jubung, and Ayas were needed to be done followed by the packaging innovation.

\section{METHODS}

The study consists of two steps, they are field study, chemical analysis. Researchers did observation related to Indonesian traditional food from Gresik city including Pudak, Jubung, and Ayas through interviews and observations related to the process of making products in Small and Medium Enterprises (SMEs) that produce these traditional foods. Chemical laboratory analysis related to the nutritional value was done by performing proximate analysis. The proximate analysis consist of moisture content by oven method, ash content by furnace method, protein content by Kjeldahl method, fat content by Soxhlet method based on Association of Official Analytical Community (AOAC (Association of Official Analytical Chemists), 1997) and analysis of carbohydrate by difference. The data is then analyzed using statistical processing software, namely Microsoft Excel and Statistical Product and Service Solution (SPSS) Version 16.0. All the data of field study and chemical analysis were used as the basic for creating the food label and packaging.

\section{Materials and Tools}

The material used consisted of two samples of Pudak, Jubung, and Ayas from two different producers (SMEs). Chemicals used for proximate analysis were hexane, $\mathrm{K}_{2} \mathrm{SO}_{4}, \mathrm{HgO}, \mathrm{H}_{2} \mathrm{SO}_{4}, \mathrm{NaOH}$, $\mathrm{Na}_{2} \mathrm{~S}_{2} \mathrm{O}_{3} .5 \mathrm{H}_{2} \mathrm{O}, \mathrm{H}_{3} \mathrm{BO}_{3}, \mathrm{HCl}$ and distilled water. The tools used include vacuum ovens, furnaces, scales, Soxhlet apparatus and Kjeldahl apparatus. 


\section{Moisture Content by Oven Methods}

The test began with drying the aluminum cup at $105^{\circ} \mathrm{C}$ for 15 minutes, then the cup was cooled in a desiccator and weighed $\left(\mathrm{W}_{2}\right)$. The sample was weighed about 2-5 grams (W) then put into a cup and dried in an oven at $105{ }^{\circ} \mathrm{C}$ for approximately three hours. After three hours, the cup containing the sample was removed from the oven and put into the desiccator then weighed $\left(\mathrm{W}_{1}\right)$. Weighing was done to obtain a fixed weight. Moisture is calculated by the following formula (1):

Moisture content $(\% w b)=$

$\frac{W-\left(W_{1}-W_{2}\right)}{W} \times 100 \%$

\section{Ash Content by Oven Methods}

The ash content analysis was carried out using the dry/furnace method. The porcelain cup to be used was dried first in an oven at $105{ }^{\circ} \mathrm{C}$ for 15 minutes then cooled in a desiccator and weighed $\left(\mathrm{W}_{2}\right)$. The sample was weighed as much as $2-5$ grams (W) in the porcelain cup and the porcelain plate containing the sample was burned to a non-smoky and blended in an electric furnace at a maximum temperature of $550{ }^{\circ} \mathrm{C}$ until complete ignition (constant weight). After the ignition process was complete, the plate contains the sample cooled in a desiccator and weighed to a fixed weight $\left(\mathrm{W}_{1}\right)$. Ash content can be calculated by the following formula (2).

$$
\text { Ash content }(\% w b)=\frac{\left(W_{1}-W_{2}\right)}{W} \times 100
$$

\section{Protein Content by Kjeldahl Method}

Determination of crude protein content with the Kjeldahl method was divided into 3 stages, namely destruction, distillation and titration. As much as 0.10.25 grams of sample weighed in a Kjeldahl flask, then added $1.0+0.1$ grams of $\mathrm{K}_{2} \mathrm{SO}_{4}, 40+10 \mathrm{ml}$ of $\mathrm{HgO}$, and $2.0+0.1$ $\mathrm{ml}$ of $\mathrm{H}_{2} \mathrm{SO}_{4}$, then the sample boiled until the clear liquid then cooled. This clear solution was transferred into a distillation device quantitatively. Kjeldahl flask was rinsed with 1-2 $\mathrm{ml}$ of distilled water, then the washing water was put into a distillation device, rinsing was done 5-6 times. Add $8-10 \mathrm{ml}$ of a solution of $60 \%$ $\mathrm{NaOH}-5 \% \quad \mathrm{Na}_{2} \mathrm{~S}_{2} \mathrm{O}_{3} .5 \mathrm{H}_{2} \mathrm{O}$ into a distillation device.

Below the condenser was an Erlenmeyer which contains $5 \mathrm{ml}$ of saturated $\mathrm{H}_{3} \mathrm{BO}_{3}$ solution and 2-4 indicator drops (mixture of 2 parts $0.2 \%$ methylene red and 1 part $0.2 \%$ methylene blue in $95 \%$ ethanol). The tip of the condenser tube must be submerged in a solution of $\mathrm{H}_{3} \mathrm{BO}_{3}$, then distillation was carried out to obtain about $15 \mathrm{ml}$ of distillate. The distillate obtained was titrated with $0.02 \mathrm{~N} \mathrm{HCl}$ until the color changes from green to gray. Rough protein levels can be calculated by the equation ( 3 and 4 ).

$$
\% \mathrm{~N}=\frac{((\mathrm{ml} \mathrm{HCl} \text { of sample }-\mathrm{ml} \mathrm{HCL} \mathrm{of} \mathrm{blank}))}{(\mathrm{mg} \mathrm{sample})} \times \mathrm{N} \text { of } \mathrm{HCl} \times 14.007 \times 100 \%
$$

$$
\text { Protein content }(\% w b)=\% N \times \text { Convertion factor }
$$

\section{Fat Content by Soxhlet Method}

The fat flask to be used was dried in an oven, then cooled in a desiccator and weighed $\left(\mathrm{W}_{2}\right)$. A total of $10 \mathrm{~g}$ of sample (W) was added with $45 \mathrm{ml}$ of hot water and $55 \mathrm{ml}$ of $25 \% \mathrm{HCl}$, then the sample was heated for 15 minutes. After being heated, it filtered using filter paper and dried in a $105^{\circ} \mathrm{C}$ oven for 3 hours. The filter paper sheath that has contained the sample was inserted into a soxhlet extraction device and connected to a condenser and fat flask. The sample was extracted with hexane solution for about 6 hours. Furthermore, hexane was distilled so that only fat remains in the flask. Fat-filled fat flasks extracted were dried in an oven at $105^{\circ} \mathrm{C}$ then cooled in a desiccator and weighed 
$\left(\mathrm{W}_{1}\right)$. Drying was repeated until it reaches a fixed weight. Fat content can be obtained by the formula (5).

$$
\text { Fat content }(\% w b)=\frac{\left(W_{1}-W_{2}\right)}{W} \times 100 \%
$$

\section{Carbohydrate Content by Difference Method}

The value of carbohydrate levels can be calculated by difference. Carbohydrate levels were calculated based on a $100 \%$ total reduction in protein, water content, ash content and fat content. This method can be calculated through the equation (6).

Carbohydrate content $(\% w b)=100-$

$(\%$ moisture $+\%$ ash $+\%$ protein $+\%$ fat $)$

(6)

\section{Data Analysis}

The data obtained were then analyzed using variance analysis (ANOVA) and continued with further Tukey's test if there were significant differences in $95 \%$ confidence level using the Statistical Product and Service Solution (SPSS) program Version 16.0. Analysis of calorie calculations using Microsoft Excel programs.

\section{RESULT AND DISCUSSION}

\section{Ingredient Composition and Process Production}

Researchers conducted a survey in the center of Gresik's special souvenirs and conducted interviews with two SMEs (Small and Medium Enterprises) that produced Pudak, Jubung, and Ayas. Gresik's traditional food production center is located in Sukodono and Lumpur village or more precisely in Gresik market area on Sindujoyo Street. Almost every household in those region produces Gresik traditional foods such as Pudak, Jubung, and Ayas. The marketing area is not only sold in stores on Sindujoyo Street, but also in Gresik tourism objects such as Giri area
(Sunan Giri tomb), Gapuro Sukolilo area (Maulana Malik Ibrahim tomb), Veteran area (Semen Gresik industry and Gresik main entrance from Surabaya, and others.

Surveys of two SMEs obtained the composition of the raw materials from Pudak, Jubung, and Ayas and their proportions (Table 1). The three products are derived products from flour (rice flour and gelatinous rice flour), but were processed and packaged in different ways. However, at a glance the three products can show the impression of being a sweet snack product and are still in the category of jenang or dodol products. According to Head of The National Agency of Drug and Food Control/NADFC Rules No. 21 year 2016 (Badan Pengawas Obat dan Makanan Republik Indonesia (BPOM), 2016) regarding the category of food products, processed rice products (number 06.7) are products made from rice including glutinous rice which undergo processing such as boiling, steaming, frying, and roasting and are formed into cakes or other forms. One of them is dodol / jenang / gelamai. Jenang is a food product obtained from glutinous rice flour, coconut milk and sugar with or without the addition of other food ingredients cooked to achieve the desired texture. The main basic characteristics of this product are not more than $20 \%$ moisture content.

Based on observation, both SMEs used the same raw material to make Pudak, Jubung, and Ayas. There are only differences in pudak products, where SMEs 1 uses Javanese sugar or brown sugar while SMEs 2 does not use Javanese sugar in addition to cane sugar. Differences in raw materials and composition will greatly affect the characteristics of the product, both physically, chemically and also sensory. The picture of these three types of products can be seen as follows in Figure 1. 
Table 1 The composition of the raw materials of Pudak, Jubung and Ayas

\begin{tabular}{|c|c|c|c|c|c|c|}
\hline \multirow[b]{2}{*}{ No } & \multicolumn{2}{|c|}{ Pudak } & \multicolumn{2}{|c|}{ Jubung } & \multicolumn{2}{|l|}{ Ayas } \\
\hline & Ingredients & $\begin{array}{l}\text { Percentage } \\
(\%)\end{array}$ & Ingredients & $\begin{array}{c}\text { Percentage } \\
(\%)\end{array}$ & Ingredients & $\begin{array}{c}\text { Percentage } \\
(\%)\end{array}$ \\
\hline 1 & Rice flour & $20-25$ & $\begin{array}{l}\text { White glutinous } \\
\text { rice }\end{array}$ & $20-25$ & White glutinous rice & $20-25$ \\
\hline 2 & Sugar & $20-25$ & $\begin{array}{l}\text { Black glutinous } \\
\text { rice }\end{array}$ & $7-25$ & Sugar & $15-20$ \\
\hline 3 & Coconut milk & $45-50$ & Sugar & $25-40$ & Coconut milk & $50-65$ \\
\hline 4 & & & Coconut milk & $20-30$ & Sesame seed & $1-2$ \\
\hline 5 & & & Sesame seed & $2-3$ & Colorant & $0.01-0.05$ \\
\hline
\end{tabular}

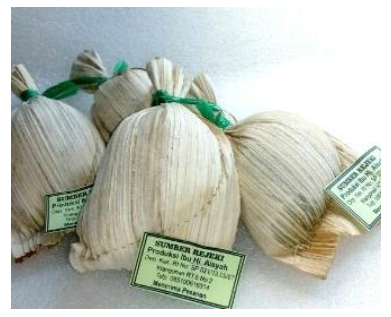

(a)

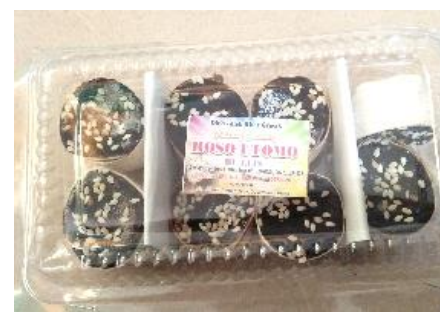

(b)

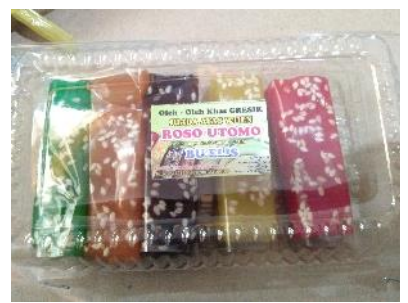

(c)

Figure 1 Gresik Traditional Food (a) Pudak, (b) Jubung, (c) Ayas

The three products in the that have high moisture content (22-55\%), manufacturing process had similar stages. low fat $(0.3-0.9 \%)$, low protein (2.12Starting from boiling coconut milk and 2.80\%) and high carbohydrate (40.85sugar, then proceed with entering sticky rice flour or rice flour into solution. As for the making of Ayas, vanilla powder and colorant were added in the initial boiling stage. The mixture was heated to form certain consistency or thickness. The next stage was packaging. Pudak and Jubung were packed with ope sheets (Pinang leaves). While Ayas were packed with plastic.

\section{Nutritional Values}

The nutritional value of a product needs to be known as information that is used to determine the product usage, storage conditions, shelf life of the product, and proposed consumers. The results of proximate test on the three products are shown in Table 2. Based on the Table 2 which describes the percentage of macronutrients in the product it can be seen that the three types of products are products $73.85 \%)$.

Dodol is a type of food made from glutinous rice flour, coconut milk and sugar with or without the addition of other permitted ingredients (BSN (Badan Standardisasi Nasional), 1992). When compared with the Indonesian National Standard on Dodol, it turns out that only the ash component meets. In the product moisture content, the three Gresik traditional products have a higher water content than $20 \%$. The condition of the water content even in Pudak's product was $55.6 \%$ significantly different from the relationship between Jubung and Ayas which have water content of $25.01 \%$ and $22.67 \%$, respectively. This high water content is possible condition for microorganisms' growth such as bacteria, yeast or mold (Winiati \& Nurwitri, 2012). Therefore packaging and proper storage conditions are needed. 
Table 2 Results of proximate analysis from Pudak, Jubung and Ayas

\begin{tabular}{|c|c|c|c|c|c|}
\hline No. & Nutritional Component & Pudak* & Jubung* & Ayas* & $\begin{array}{l}\text { Indonesian } \\
\text { Standard } \\
\text { Dodol** }\end{array}$ \\
\hline 1 & Water content (\%) & $55.63 \pm 1.24^{\mathrm{b}}$ & $25.01 \pm 3.21^{\mathrm{a}}$ & $22.67 \pm 0.86^{\mathrm{a}}$ & Max. $20 \%$ \\
\hline 2 & Ash content $(\%)$ & $0.41 \pm 0.01^{\mathrm{ab}}$ & $0.49 \pm 0.09^{b}$ & $0.38 \pm 0.01^{\mathrm{a}}$ & $\operatorname{Max} 1.5 \%$ \\
\hline 3 & Fat content $(\%)$ & $0.98 \pm 0.28^{b}$ & $0.42 \pm 0.19^{\mathrm{a}}$ & $0.30 \pm 0.26^{\mathrm{a}}$ & Min. $7 \%$ \\
\hline 4 & Protein content $(\%)$ & $2.12 \pm 0.19^{\mathrm{a}}$ & $2.75 \pm 0.53^{\mathrm{b}}$ & $2.80 \pm 0.02^{\mathrm{b}}$ & Min. $3 \%$ \\
\hline 5 & Carbohydrate content (\%) & $40.85 \pm 0.77^{\mathrm{a}}$ & $71.32 \pm 2.40^{\mathrm{b}}$ & $73.85 \pm 0.62^{c}$ & - \\
\hline
\end{tabular}

Table 3 Nutritional Value of Pudak, Jubung and Ayas

\begin{tabular}{lllllll}
\hline \multirow{2}{*}{$\begin{array}{l}\text { Nutritional } \\
\text { Values }\end{array}$} & \multicolumn{2}{c}{ Pudak (90 g per serving) } & \multicolumn{2}{c}{ Jubung (40 g per serving) } & \multicolumn{2}{c}{ Ayas $(60$ g per serving) } \\
\cline { 2 - 7 } & Quantity $(\mathrm{g})$ & $\begin{array}{l}\text { Calories } \\
(\mathrm{kcal})\end{array}$ & Quantity $(\mathrm{g})$ & $\begin{array}{l}\text { Calories } \\
(\mathrm{kcal})\end{array}$ & Quantity $(\mathrm{g})$ & $\begin{array}{l}\text { Calories } \\
(\mathrm{kcal})\end{array}$ \\
\hline Fat & 0.88 & 7.94 & 0.17 & 1.51 & 0.18 & 1.62 \\
Protein & 1.91 & 7.63 & 1.10 & 4.40 & 1.68 & 6.72 \\
Carbohydrate & 36.77 & 147.06 & 28.53 & 114.11 & 44.31 & 177.24 \\
Total & & 162.63 & & 120.02 & & 185.58 \\
\hline
\end{tabular}

At the fat content, these three products have a low fat content, which is under $1 \%$. This value is very far compared to the standard of dodol which shows that the minimum fat content is $7 \%$. In theory, high fat content comes from dodol raw material, namely coconut milk. Based on the results of field observations, the three products used coconut milk in a high percentage, but the results of fat content testing with the Soxhlet method showed a low value. For determining the oil or fat content, the material tested must be dry enough, because if it is still wet in addition to slowing down the extraction process, water can drop into the flask and will affect the calculation (AOAC (Association of Official Analytical Chemists), 1997). The condition of products that do have high water content is a mutually influencing factor in this proximate test.

The three products almost meet the criteria for protein content, which is at least $3 \%$. The protein content of Pudak was lower $(2.12 \%)$ and significantly different from Jubung $(2.75 \%)$ and Ayas $(2.80 \%)$. The content of sesame seeds is one of the factors that causes Jubung and Ayas to have a higher protein content than fats. Sesame seeds contain 50-53\% sesame oil, $20 \%$ protein, $7-8 \%$ crude fiber, $15 \%$ nitrogen-free residues, and 4.5-6.5\% ash (Ma'arief, Yudono, \& Taryono, 2013).

Calculation of the amount of carbohydrates in the product shows that these three products are the source of carbohydrates (40.85-73.85\%). These carbohydrates then need to be tested further considering that the types of carbohydrates that may be contained in products are very diverse. Carbohydrate types of products include starch, sugar (sucrose) and also crude fiber (Kusnandar, 2010). As for Indonesian National Standard (SNI) about Dodol, it is explained that the standard of Dodol carbohydrates includes sugar calculated as sucrose with a minimum of $40.0 \%$ and a maximum crude fiber of $1.0 \%$ (BSN (Badan Standardisasi Nasional), 1992).

\section{CONCLUSION}

Indonesian traditional food from Gresik city, Pudak, Jubung and Ayas are made from similar raw materials, namely rice flour (in Pudak), glutinous rice flour (in Jubung and Ayas), sugar and coconut milk. The third difference in the product lies in the composition of different ingredients and whether or not there are additions of sesame seeds and colorant. The three products are categories as Jenang or Dodol according to NADFC rules. The 
proximate test results showed that Pudak has moisture content $(55.6 \%)$ twice higher than Pudak and Ayas (25.0\% and 22.7\%, respectively). All three products have a low fat content, which was below $1.0 \mathrm{~g}$ per serving. The protein content is also relatively low, i.e. only $2.1-2.8 \%$. All three of these products are sources with the amount of $40.8-73.4 \%$ which gives a caloric amount of 120-185 kcal per serving. Thus, the nutritional information can be developed for the writing of food labels and also the basis for the development of appropriate preservation technology innovations and also the innovation of nutritional value of the product.

\section{REFERENCES}

Agustina, T. K., \& P, J. H. (2017). Pengaruh Sanggar Batik Rumpaka Mulya Wringinanom Terhadap Perkembangan Batik Loh Bandeng Gresik Tahun 2005-2012, 5(3), 440 448. Retrieved from http://jurnalmahasiswa.unesa.ac.id/i ndex.php/avatara/article/viewFile/19 $382 / 17700$

AOAC (Association of Official Analytical Chemists). (1997). In P. A. Cunniff (Ed.), Official methods of analysis of AOAC international (16th ed.. Arlington, Virginia, USA: AOAC International. Association of Official Agricultural Chemists., 1(Volume $1)$. https://doi.org/10.1371/journal.pone. 0013135

Badan Pengawas Obat dan Makanan Republik Indonesia (BPOM). (2016). PerKa BPOM no 21 tahun
2016 Tentang Kategori Pangan, 128.

Basito. (2009). Sifat Fisik, Kimia, dan Organoleptik pada Pembuatan Dodol yang Disubtitusi dengan Wortel (Daucus carota, Linn). Jurnal Teknologi Hasil Pertanian, II(2), 104-111.

BSN (Badan Standardisasi Nasional). (1992). SNI 01-2986-1992: Dodol.

Ilma, N. (2012). Studi Pembuatan Dodol Buah Dengen (Dillenia serrata Thunb). Universitas Hasanuddin.

Kusnandar, F. (2010). Kimia pangan komponen makro. Dian Rakyat. Jakarta (Vol. 264).

Ma'arief, M. S., Yudono, P., \& Taryono. (2013). Keragaan Sembilan Kultivar Wijen (Sesamum indicum L.) dalam Berbagai Tingkat Salinitas. Vegetalika, 2(1), 1-9. Retrieved from

https://jurnal.ugm.ac.id/jbp/article/vi ew/1621/1434

Mardhiyyah, Y. S., \& Wijaya, C. H. (2012). Manggulu Pangan Lokal Berkalori Tinggi yang Kaya Serat Alami. Jurnal Pangan, 21(23), 259269. Retrieved from http://www.jurnalpangan.com/index. php/pangan/article/view/173

Suter, I. K. (2014). Pangan Tradisional : Potensi dan Prospek Pengembangannya. Media Ilmiah Teknologi Pangan, 1(1), 96-109.

Winiati, P. R. (IPB), \& Nurwitri, C. C. (IPB). (2012). Mikrobiologi pangan. Bogor: IPB Press. 